\title{
WASTEWATER CHARACTERIZATION OF PAHARRANG DRAIN IN FAISALABAD AND EVALUATION OF SUBSURFACE CONTAMINATION USING GEOGRAPHICAL INFORMATION SYSTEM
}

\author{
Haroon Rashid*, Atif Bilal Asad, Abdul Nasir, Arslan Chaudhary, Asma Sattar
}

\section{Department of Structurers and Environmental Engineering, University of Agriculture, Faisalabad *Corresponding Author Email: haroon.rashid@uaf.edu.pk}

This is an open access article distributed under the Creative Commons Attribution License, which permits unrestricted use, distribution, and reproduction in any medium, provided the original work is properly cited.

\section{ARTICLE DETAILS}

Article History:

Received 26 June 2018 Accepted 2 July 2018

Available online 1 August 2018

\section{ABSTRACT}

\begin{abstract}
Due to improper management of municipal wastewater in urban areas, most of the drains passing through major cities have converted to industrial effluent carrying drains with immensely excessive contamination loads. Same is the case with the Paharrang drain in Faisalabad, which was once storm water carrying drain but presently it is highly polluted by industrial wastes. This research work was conducted in order to determine the level of contamination in this drain and to find out its impact on soil and groundwater. Due to unlined drain, the untreated industrial wastewater is percolating down into the soil and finally mixing with groundwater. In this regard the research area was thoroughly investigated to find the concentration of major contaminants in wastewater, groundwater and soil. Sampling points of groundwater were selected keeping in view the relative position from the drain. Soil samples were collected to understand the mobility of contaminants. The groundwater samples were analyzed for different parameters such as $\mathrm{pH}, \mathrm{EC}$, TDS, TSS, BOD, COD, $\mathrm{Pb}, \mathrm{Cd}, \mathrm{Cu}$, and $\mathrm{Cr}$. The results of this analyzed parameter were compared with WHO guidelines. The results of these analyzed parameters were represented by mapping using ArcView GIS v9.3 and IDW was used for raster interpolation. Statistical approach was adopted for analysis of these concentrations and GIS. In soil samples excessive heavy metals content was found and 80 percent soil samples had pH within permissible limit.
\end{abstract}

\section{KEYWORDS}

Paharrang drain, Faisalabad, wastewater characteristics, soil and groundwater contamination, GIS.

\section{RESEARCH BACKGROUND}

Haphazard industrialization and lack of awareness about environmental issues is one of the major causes of the intensive impact of pollution on environment and human life in developing countries. Most of the industries are developed without any kind of planning and prior provision of measures to control the spread of contamination. Industrial pollution is a very serious issue all over the world which deteriorate physical, chemical and biological properties of soils, air and waters and all combine to pose health threats to plants, animals and humans. In general groundwater is abstracted annually for the world can be sited at $750-800 \mathrm{~km}^{3}$ that is approximately one sixth of total fresh water [1].

Faisalabad city has made rapid progress in industry after freedom. It is famous for its different industries such as paper, leather, textile, sugar, vegetable oil, dying industries, soaps, detergents, and many other industries [2]. As a result of these industries large amount of organic and inorganic solid waste and wastewater which contains heavy metals is being disposed off into natural streams and drains. These heavy metals and other pollutants are reasonably harmful to environment, groundwater, surface water and health of humans, plants and animals.

Faisalabad, the $3^{\text {rd }}$ largest city of Pakistan with its population more than 4 million, is well known for having numerous industries pertaining to various sectors. Faisalabad is the major contributor to GDP of Pakistan i.e. over $20 \%$. Basically it is center of Textile industry in Pakistan constituting of more than $65 \%$ of textile export market of Pakistan. All these production units produce wastewater in immense quantity therefore wastewater management and industrial effluent in particular is one of the major environmental issue of Faisalabad city [3]. It is situated on flat topography which does not allow disposal of sewage and storm water from the city through gravity flow. For this purpose, multistage pumping is frequently done by WASA Faisalabad for disposal of the wastewater, which needs immense quantity of resources, power supply and finances. Furthermore, as most of the wastewater is carrying industrial effluent therefore it becomes a potential hazard for the residents of the city who are bound to use external source for drinking purpose due to deterioration of groundwater by industrial effluent leaching. This large amount of water contains high contamination of effluents.

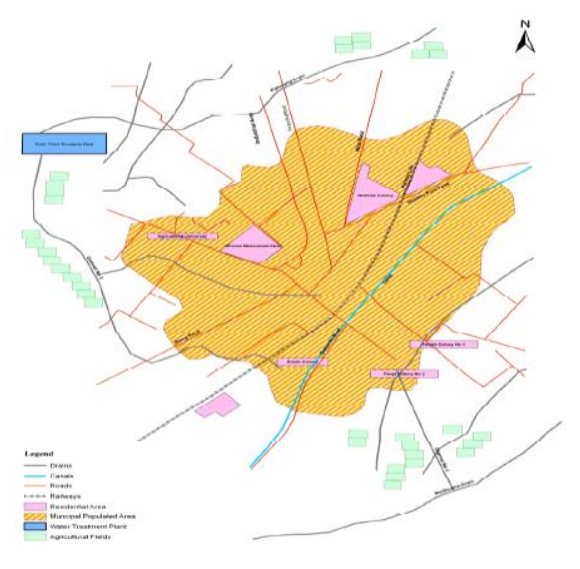

Figure 1: Map of Faisalabad City 
The city Faisalabad is divided into two zones (Western and Eastern). The North Western area is drained through Paharang Drain which eventually discharges into River Chenab. The east area of the canal slopes towards the South-East and drains into the Madhuana Drain which discharges into Ravi River. Total capacity of the wastewater treatment plant developed by WASA is 20 MGD approximately. But it does not treat the wastewater coming from Industrial units. Therefore, it is expected that each industry, before it disposes the effluent, must make arrangement to treat the industrial effluent and follow NEQS, which are set in order to control the wastewater characterization of the industrial effluent being disposed into the drains [4].

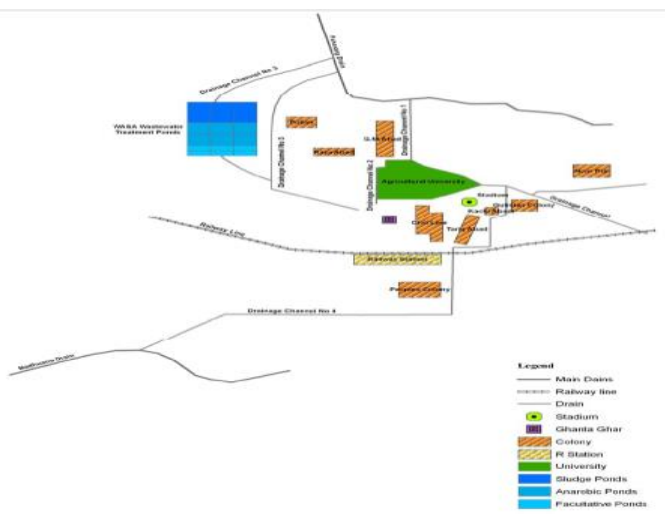

Figure 2: Drain System of Faisalabad

The Faisalabad city generated 280 MGD sewer water and there is lack of wastewater treatment facility to address such huge amount of wastewater. Therefore, most of the drains are carrying untreated effluent all the way to its final disposal into the rivers [5]. Thus there is high probability that this untreated wastewater, which contains high amounts of contaminants may percolate into the soil and mix with groundwater as the drains are not completely lined to protect seepage.

Impact of wastewater on soil, is mainly due to the presence of high nutrient contents (Nitrogen and Phosphorus), high total dissolved solids and other constituents such as heavy metals, which are added to the soil over time. Wastewater can also contain salts that may accumulate in the root zone with possible harmful impacts on soil health and crop yields. The leaching of these salts below the root zone may cause soil and groundwater pollution. Prolonged use of saline and sodium rich wastewater is a potential hazard for soil as it may erode the soil structure and effect productivity. This may result in the land use becoming no sustainable in the long run.

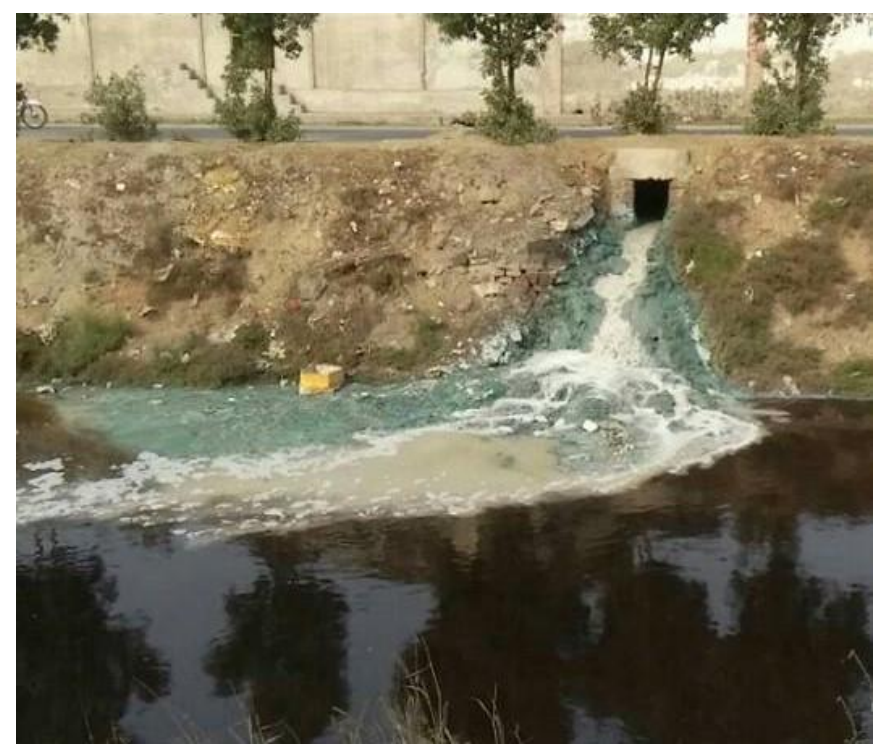

Figure 3: Paharang Drain

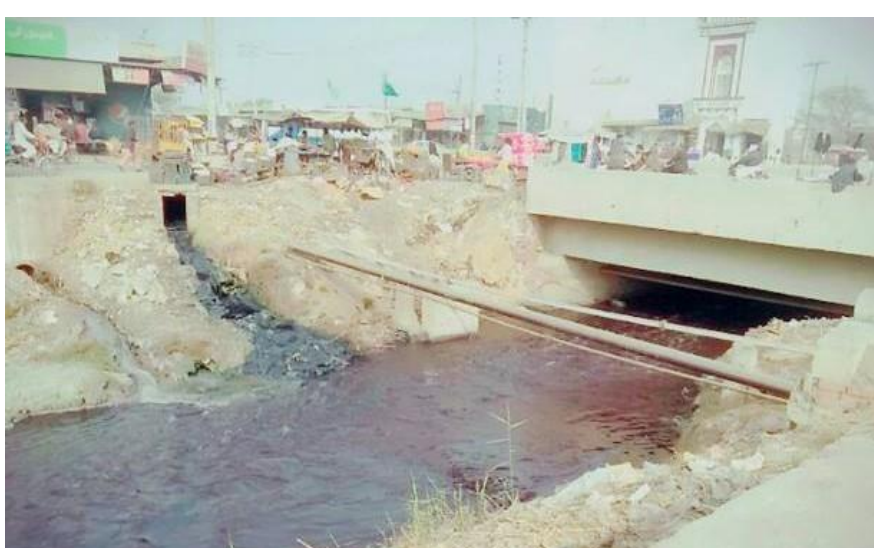

Figure 4: Bawa Chak Faisalabad

In order to address the major environmental issues related to drain, this research work was planned to determine the daily variation in effluent discharge rate and to characterize wastewater and sludge to investigate pollution loads in the Paharang Drain, to analyze groundwater and soil sample in order to determine the seepage effects of untreated effluent of the drain and to work out spatial variation of concentrations in soil and groundwater by applying GIS technique in the study area [6].

\section{MATERIALS AND METHODS}

The study area was selected on both sides of Paharang drain between Esmail road and Sargodha road. The length of Paharang drain in study area was $1.3 \mathrm{Km}$. Study area was extended $2 \mathrm{Km}$ left and $2 \mathrm{~km}$ right side of the drain. Total study area was about $6 \mathrm{Km}^{2}$. Most of the study area is industrialize, Samana stop Sargodha road and Punjab Small Industrial Estate comprises large number of industries.

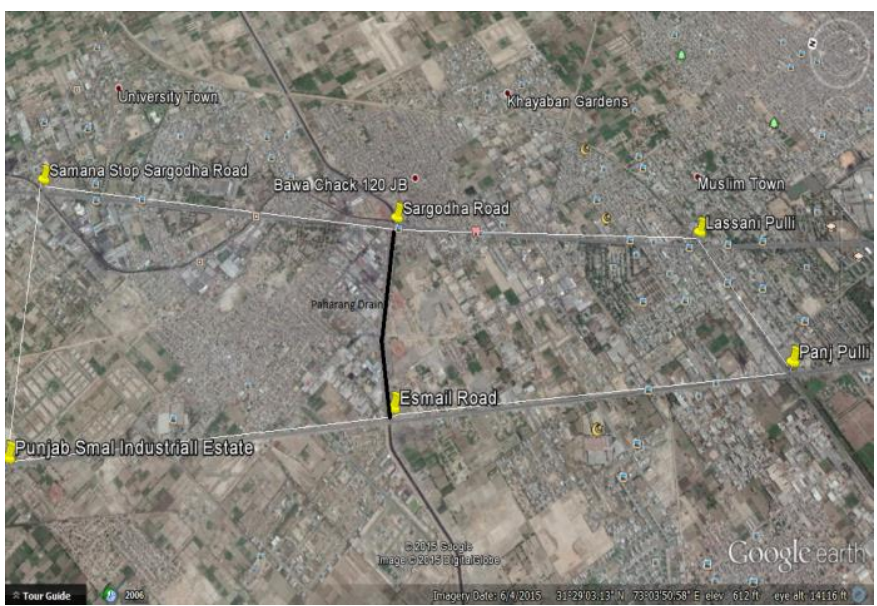

Figure 5: Study Area

Research was conducted as follow:

1: Discharge Calculation

2: Sampling

3: Analysis and Characterization

4: Evaluation

\subsection{Discharge Calculation}

Discharge of drain was calculated twice in a day for a period of week from three different points. The points were selected at the locations where industries discharge their effluent into the drain. The purpose of calculation of discharge is to determine the total flow rate of the drain. Discharge was calculated by floating method. To determine the discharge of Paharrang drain, Floating method was used. The discharge is measured by using equation:

$\mathrm{Q}=$ cross sectional Area * velocity 
$0.71 \mathrm{~m}$ and width was $7 \mathrm{~m}$. The cross sectional area of the drain was $4.97 \mathrm{~m}^{2}$ by using formula:

Cross Sectional Area of Drain $=$ Depth $*$ Width

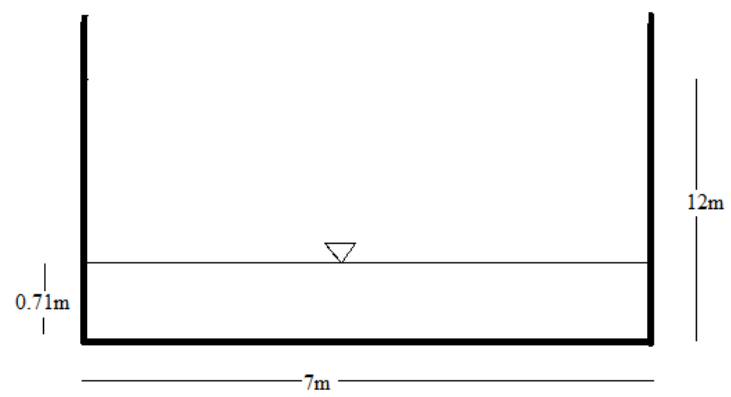

Figure 6: Drain dimensions

The discharge is calculated in $\mathrm{m}^{3} \mathrm{sec}^{-1}$.

Table 1: Discharge Rate

\begin{tabular}{|c|c|c|c|c|c|c|c|}
\hline Days & Saturday & Sunday & Monday & Tuesday & Wednesday & Thursday & Friday \\
\hline Units & $\mathrm{m}^{3} \mathrm{~s}^{-1}$ & $\mathrm{~m}^{3} \mathrm{~s}^{-1}$ & $\mathrm{~m}^{3} \mathrm{~s}^{-1}$ & $\mathrm{~m}^{3} \mathrm{~s}^{-1}$ & $\mathrm{~m}^{3} \mathrm{~s}^{-1}$ & $\mathrm{~m}^{3} \mathrm{~s}^{-1}$ & $\mathrm{~m}^{3} \mathrm{~s}^{-1}$ \\
\hline $\begin{array}{c}\text { Discharge } \\
\text { Rate at } \\
\text { 11:00am }\end{array}$ & 2.18 & 2.20 & 2.18 & 2.26 & 2.25 & 2.19 & 1.98 \\
\hline $\begin{array}{c}\text { Discharge } \\
\text { Rate at } \\
\text { 5:00pm }\end{array}$ & 2.23 & 2.25 & 2.25 & 2.45 & 2.41 & 2.36 & 2.20 \\
\hline
\end{tabular}

\subsection{Soil Sampling}

Wastewater pollutants may contaminate soil of the study area. There for four samples were taken up to the depth of $4 \mathrm{~m}$. First sample was collected from $1 \mathrm{~m}$ depth and second sample was taken from the depth of $4 \mathrm{~m}$. Total 4 samples were collected from 2 different points situated at both sides of the drain. The distance of the sampling point from drain was $15 \mathrm{~m}$. The quantity of each sample was approximately $500 \mathrm{~g}$. Took another sample by boring up to the depth of $4 \mathrm{~m}$. Both these bags were labeled by number, depth, date, time and bore point. Same procedure was adopted for second sampling point.

\section{$2.3 \quad$ Sludge Sampling}

Sludge samples were collected from two points. These points were starting and end points of drain in the study area. Two sludge samples were collected. The tools used for sludge sampling was gloves, trowel, spade and a plastic bottle. The quantity of sludge samples were $500 \mathrm{~g}$. These sludge samples were transported to Sitara chemical laboratories as quickly as possible.

\subsection{Wastewater Sampling}

Wastewater samples were collected from Paharang drain. The samples were collected from 15 different points. Total 8 samples were collected and the quantity of each sample was $500 \mathrm{~mL}$. The tools used for wastewater sampling were bucket attach with a stick, funnel and PVC bottles.

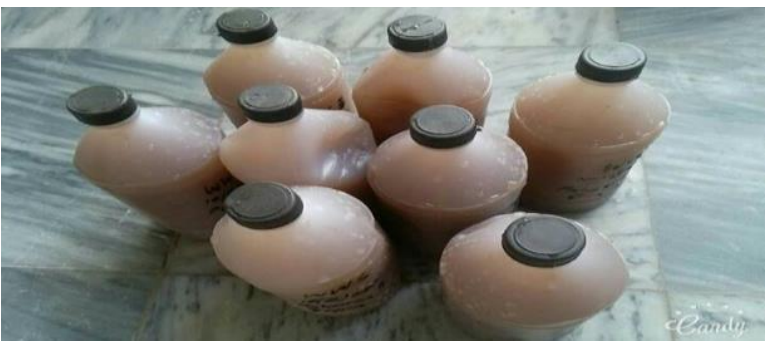

Figure 7: Wastewater Samples

\subsection{Groundwater Sampling}

Groundwater samples were collected randomly throughout the study area on both sides of the drain from 30 different points. GPS coordinates were measured from each sampling point. Total 30 groundwater samples were collected. Groundwater samples were collected from pumps, motors, hand pumps and tube wells. The samples were collected in PVC bottles. The quantity of each sample was $500 \mathrm{~mL}$. For groundwater sampling PVC bottles and GPS meter was used.

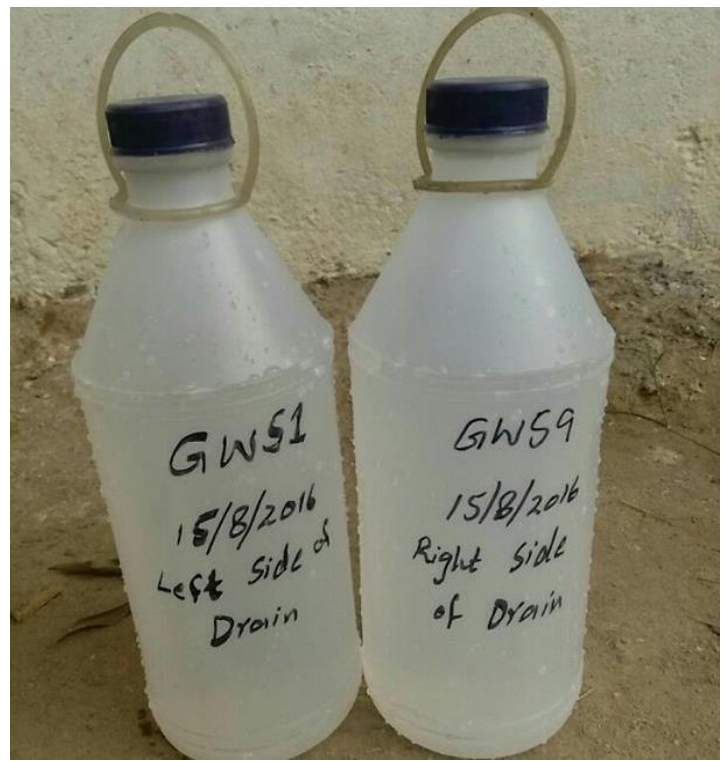

Figure 8: Groundwater Samples

The following analysis was performed for present research work.

1. $\mathrm{pH}$

2. Electrical Conductivity (EC)

3. Total Dissolved Solids (TDS)

4. Total Suspended Solids (TSS)

5. Biological Oxygen Demand (BOD 5 )

6. Chemical Oxygen Demand (COD)

7. Sodium Adsorption Ratio (SAR)

8. Residual Sodium Carbonate (RSC)

9. Lead $(\mathrm{Pb})$

10. Cadmium $(\mathrm{Cd})$

11. Copper $(\mathrm{Cu})$

12. Chromium (Cr)

\subsection{1 $\quad p H$}

$\mathrm{pH}$ of each sample was determined with the help of digital $\mathrm{pH}$ meter following the guidelines of AOAC (2007).

\subsubsection{Electrical Conductivity}

Electrical Conductivity EC was determined by using EC-Model no. TOA-IM40S. Calibration was performed using standard buffer solution.

\subsubsection{Total Dissolved Solids (TDS)}

Total Dissolved Solids (TDS) was determined by ignition of residue method (Greenberg et al., 1992).

\subsubsection{Total Suspended Solids (TSS)}

Total Suspended Solids (TSS) was measured by standard method described by (APHA, 2003).

\subsubsection{Biochemical Oxygen Demand (BOD)}


The sample was filled in an airtight bottle and incubated at specific temperature for 5 days. The dissolved oxygen (DO) content of the sample was determined before and after five days of incubation at $20^{\circ} \mathrm{C}$ and the $\mathrm{BOD}_{5}$ is calculated from the difference between initial and final DO (APHA, 2003).

\subsubsection{Chemical Oxygen Demand (COD)}

Chemical Oxygen Demand (COD) was determined by using standard method described by APHA (2003).

\subsection{Heavy Metal Determination}

The heavy metals, lead $(\mathrm{Pb})$, Copper $(\mathrm{Cu})$, Chromium $(\mathrm{Cr})$ and Cadmium (Cd) were determined by using standard analytical techniques (APHA, 2003) with the help of atomic absorption Spectrophotometer for samples from groundwater, wastewater, sludge and soil.

\section{RESULTS AND DISCUSSION}

\subsection{Discharge measurement}

Discharge rate calculations were conducted twice for a week. The discharge of the drain was almost same in a day but vary day to day. Discharge is maximum on Tuesday and Wednesday while, minimum in Friday morning.

Table 2: Discharge Rate Determinations

\begin{tabular}{|l|l|l|l|}
\hline Day & $\begin{array}{l}\text { Discharge } \\
\text { Rate } \\
\text { 11:00Am }\end{array}$ & $\begin{array}{l}\text { Discharge } \\
\text { Rate 5:00PM }\end{array}$ & $\begin{array}{l}\text { Average Discharge } \\
\text { Rate }\end{array}$ \\
\hline Units & $\mathrm{m}^{3} \mathrm{~s}^{-1}$ & $\mathrm{~m}^{3} \mathrm{~s}^{-1}$ & $\mathrm{~m}^{3} \mathrm{~s}^{-1}$ \\
\hline Saturday & 2.18 & 2.23 & 2.205 \\
\hline Sunday & 2.20 & 2.25 & 2.225 \\
\hline Monday & 2.18 & 2.25 & 2.215 \\
\hline Tuesday & 2.26 & 2.45 & 2.355 \\
\hline Wednesday & 2.25 & 2.41 & 2.330 \\
\hline Thursday & 2.19 & 2.36 & 2.275 \\
\hline Friday & 1.98 & 2.20 & 2.090 \\
\hline
\end{tabular}

It was noted that discharge of the drain at morning was same for the first day. It was noted that discharge vary in a same day. This may be because of the work load on the industries which discharge their wastewater in the drain. The maximum discharge was $2.45 \mathrm{~m}^{3} \mathrm{~s}^{-1}$ noted on Tuesday at 5:00PM and minimum discharge was noted on Friday morning 11:00AM.

\section{$3.2 \mathrm{pH}$}

The analysis performed for $\mathrm{pH}$ by using digital $\mathrm{pH}$ meter. The $\mathrm{pH}$ analysis was performed for drain wastewater; drain sludge, soil and groundwater analysis. The values for both wastewater and sludge analysis for the drain varies between 8.99 to 11.8 with the average mean value was $10.657 \pm$ 0.921 whereas the values for groundwater were ranging between 6.80 to 9.00 with the mean value $8.00 \pm 0.13$. Analysis of variance (ANOVA) under the complete randomize design (CRD) showed that the results were nonsignificant for the groundwater analysis.

Obtained values after analysis were compared with standard values of USEPA for drinking water, FAO for irrigation water and NEQS for water treatment. Standard values for drinking water, wastewater and irrigation water are given in appendix. According to the NEQS standards the normal value for hydrogen ion concentration $(\mathrm{pH})$ is ranging between 6.5 to 7.5 for drinking purposes and up to 8 for irrigation as described in food and agriculture organization (FAO) papers.
Table 3: Statistical analysis of $\mathrm{pH}$ for Wastewater, Sludge and Soil

\begin{tabular}{|l|l|l|l|l|}
\hline $\begin{array}{l}\text { Statistical } \\
\text { analysis }\end{array}$ & Wastewater & Sludge & Soil \\
\hline \multirow{2}{*}{ Mean } & $\begin{array}{l}10.657 \quad \pm \\
0.921\end{array}$ & $\begin{array}{l}10.775 \quad \pm \\
1.26\end{array}$ & $8.5 \pm 2.055$ \\
\hline SD & 0.21 & 1.26 & 2.055 \\
\hline \multirow{2}{*}{ Range } & Min & 8.99 & 9.1 & 7.8 \\
\cline { 2 - 6 } & Max & 11.8 & 11.9 & 8.9 \\
\hline
\end{tabular}

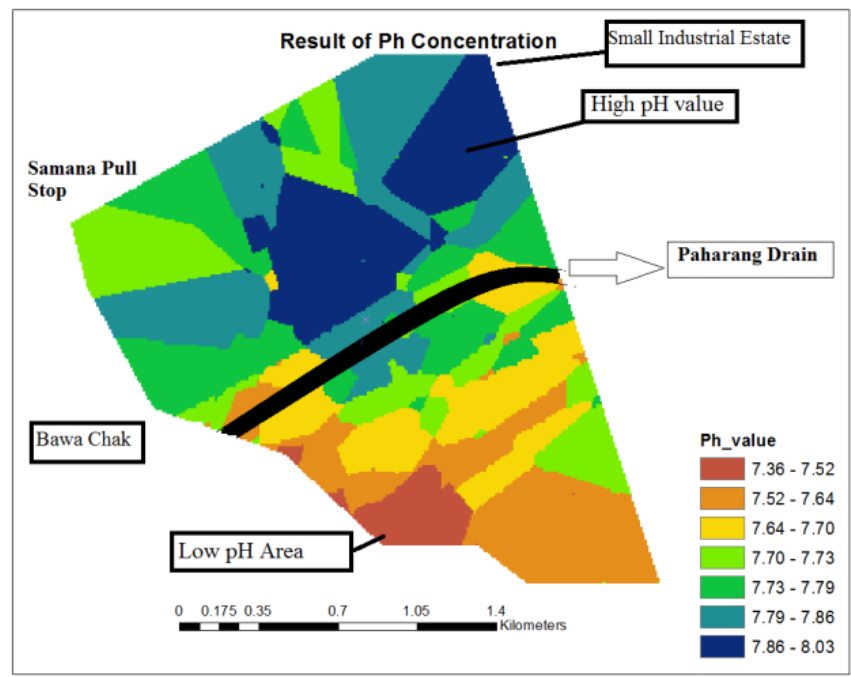

Figure 9: GIS map of $\mathrm{pH}$

The GIS study explores the results that $\mathrm{pH}$ level was very high in drain wastewater. It shows the high level of alkaline particles in the wastewater. The Groundwater samples have high values of $\mathrm{pH}$ along the drain and it was also observed that $\mathrm{pH}$ values were higher in samples taken from areas on left side rather than that on right side of the drain. This shows that the lateral movement of wastewater particles is more towards the left side than the right side of the drain due to Groundwater flow pattern.

\subsection{Electrical Conductivity (EC)}

The analysis performed for EC by using digital EC meter. EC analysis was performed for drain wastewater; drain sludge, soil and groundwater analysis. The values for both wastewater and sludge analysis for the drain varies between 4.825 to 6.123 and 6.708 to 8.176 respectively. Whereas the average means value was $5.4278 \pm 0.4478$ for drain wastewater and $7.6975 \pm 0.6786$ for sludge analysis. On the other hand the EC values for groundwater were ranging between 0.239 to 6.020 with the mean values $1.75033 \pm 0.125$. Analysis of variance (ANOVA) under the complete randomize design (CRD) showed that the results are significant for the groundwater analysis.

Obtained values after analysis were compared with standard values of USEPA for drinking water, FAO for irrigation water and NEQS for water treatment. Standard values for drinking water, waste water and irrigation water are given in appendix. According to the NEQS standards the normal value for electrical conductivity (EC) is $5500 \mathrm{mS} / \mathrm{m}$ for wastewater and sludge whereas for groundwater drinking purposes it should not be more than $850 \mathrm{mS} / \mathrm{m}$. For irrigation water the EC value has importance and not over than $1500 \mathrm{mS} / \mathrm{m}$ as described in food and agriculture organization (FAO) papers.

Table 4: Statistical analysis of EC of Wastewater, Sludge and Soil

\begin{tabular}{|c|c|c|c|c|}
\hline \multicolumn{2}{|c|}{$\begin{array}{l}\text { Statistical } \\
\text { analysis } \\
\text { Mean }\end{array}$} & Wastewater & Sludge & Soil \\
\hline & $\begin{array}{l}5.4278 \\
0.4478\end{array}$ & $\begin{array}{ll}7.6975 \\
0.6786\end{array}$ & $4.2725 \pm 0.8254$ \\
\hline \multicolumn{2}{|l|}{ SD } & 0.4478 & 0.6786 & 0.8254 \\
\hline \multirow[t]{2}{*}{ Range } & Min & 4.825 & 6.708 & 3.56 \\
\hline & Max & 6.123 & 7.6975 & 5.76 \\
\hline
\end{tabular}




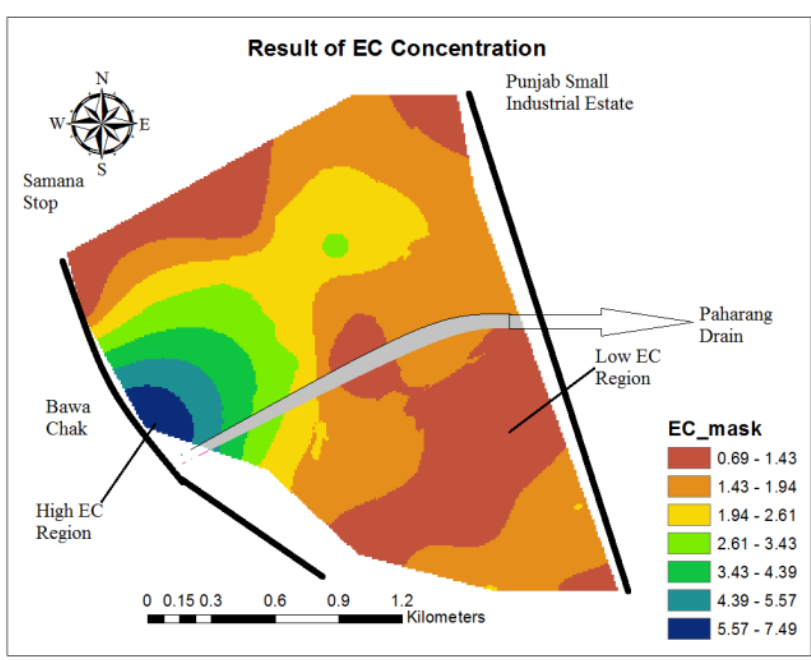

Figure 10: GIS map of EC

GIS map shows different areas with their EC value concentrations which are differentiated with different legends. The lowest EC was found in the sample taken from the area near the canal water from Lassani Pulli and away from the drain. The Highest EC concentration was found from the sample taken from the area situated near Sargodha road at Bawa Chak.

\subsection{Total Dissolved Solids (TDS)}

The analysis performed for TDS by using oven dry method. TDS analysis was performed for groundwater. The TDS analysis for groundwater was ranging between $212 \mathrm{mg} / \mathrm{L}$ to $1995 \mathrm{mg} / \mathrm{L}$ with the mean value $1078.33 \pm$ $0.13 \mathrm{mg} / \mathrm{L}$. Analysis of variance (ANOVA) under the complete randomize design (CRD) showed that the results are significant for the groundwater analysis.

Obtained values after analysis were compared with standard values of USEPA for drinking water, FAO for irrigation water and NEQS for water treatment. Standard values for drinking water, waste water and irrigation water are given in appendix.

Table 5: Analysis of Variance of TDS for Groundwater

\begin{tabular}{|l|l|l|l|l|l|}
\hline Source & DF & SS & MS & F & P \\
\hline Rep & 2 & 17647 & 8824 & $0.14^{*}$ & 0.870 \\
\hline Error & 87 & 5501945 & 63241 & & \\
\hline Total & 89 & 5519592 & & & \\
\hline
\end{tabular}

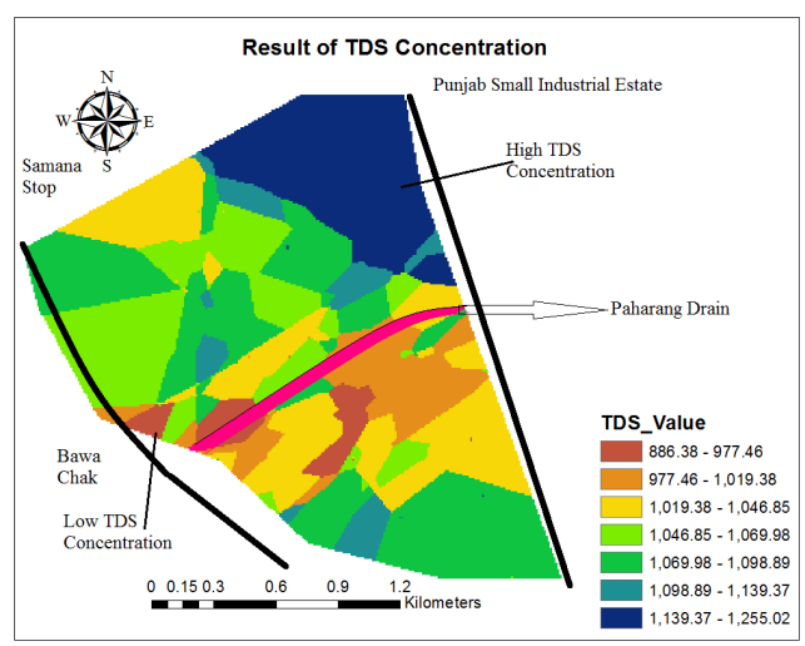

Figure 11: GIS map of TDS

GIS map shows different areas with their TDS value concentrations which are differentiated with different legends. The lowest TDS was found in the sample taken from the area found in the centre of study area. The Highest TDS concentration was found from the sample taken from the area near the panj pulli. The GIS study explores the results which shows that TDS level was very high in groundwater sample. It shows the high level of salty particles in wastewater.

\subsection{Total Suspended Solid (TSS)}

The analysis performed for TSS by using oven dry method also. TSS analysis was performed for groundwater analysis. The TSS analysis for groundwater was ranging between $90 \mathrm{mg} / \mathrm{L}$ to $215.9 \mathrm{mg} / \mathrm{L}$ with the mean value $198.23 \pm 2.81 \mathrm{mg} / \mathrm{L}$. Analysis of variance (ANOVA) under the complete randomize design (CRD) showed that the results were nonsignificant for the groundwater.

Obtained values after analysis were compared with standard values of USEPA for drinking water, FAO for irrigation water and NEQS for water treatment. Standard values for drinking water, wastewater and irrigation water are given in appendix. According to the NEQS standards the normal value for total suspended solids (TSS) is $400 \mathrm{mg} / \mathrm{L}$ for wastewater and groundwater drinking purposes it should not be more than $150 \mathrm{mg} / \mathrm{L}$. For irrigation water the TSS value is not also taken under consideration.

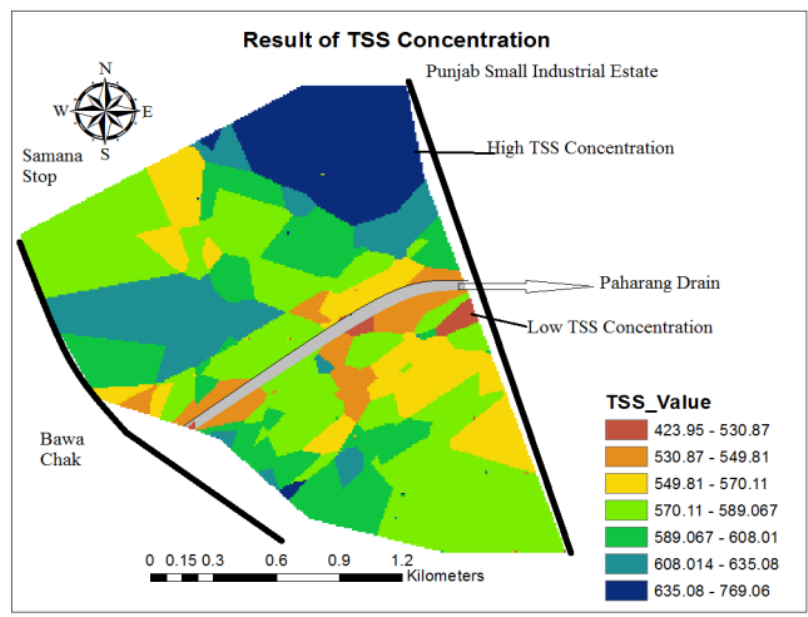

Figure 12: GIS map of TSS

The GIS study explores the results which shows that TSS level was very high in groundwater samples near the Small Industrial Estate. The trend of lateral movement of wastewater particles was observed towards left side more than the right side. It was also observed moderately high concentration of TSS near Bawa Chak. GIS map shows that TSS concentration is moderate at Lassani pulli.

\subsection{Biological Oxygen Demand (BOD $\left.{ }_{5}\right)$}

Biological oxygen demand $\left(\mathrm{BOD}_{5}\right)$ analysis was performed for drain wastewater analysis. The values drain wastewater analysis varies between $201 \mathrm{mg} / \mathrm{L}$ to $311 \mathrm{mg} / \mathrm{L}$, such results showed pollution concentration. Whereas the average mean value was found $258.1 \pm 42.36$ $\mathrm{mg} / \mathrm{L}$ for drain wastewater samples.

Obtained values after analysis were compared with standard values of USEPA for wastewater, FAO for irrigation water and NEQS for water treatment. Standard values wastewater is given in appendix. According to the NEQS standards the allowable limit value for biological oxygen demand $\left(\mathrm{BOD}_{5}\right)$ is $200 \mathrm{mg} / \mathrm{L}$ for wastewater.

Table 6: Statistical Analysis of BOD for Wastewater

\begin{tabular}{|l|l|}
\hline Statistical Analysis & Wastewater \\
\hline Average & $258.1 \pm 42.36$ \\
\hline SD & 42.36 \\
\hline Min & 201 \\
\hline Max & 311 \\
\hline
\end{tabular}

\subsection{Chemical Oxygen Demand (COD)}

Chemical oxygen demand (COD) analysis was performed for drain wastewater analysis. The values drain wastewater analysis varies between $135 \mathrm{mg} / \mathrm{L}$ to $215 \mathrm{mg} / \mathrm{L}$, such results showed pollution concentration. Whereas the average mean value was found $179.8 \pm 22.78$ $\mathrm{mg} / \mathrm{L}$ for drain wastewater samples. Obtained values after analysis were 
compared with standard values of USEPA for wastewater, FAO for irrigation water and NEQS for water treatment. Standard values for wastewater is given in appendix. According to the NEQS standards the allowable limit value for chemical oxygen demand (COD) is $150 \mathrm{mg} / \mathrm{L}$ for sewerage and industrial effluent.

Table 7: Statistical Analysis of COD for Wastewater

\begin{tabular}{|l|l|}
\hline Statistical Analysis & Wastewater \\
\hline Average & $179.8 \pm 22.78$ \\
\hline SD & 22.78 \\
\hline Min & 135 \\
\hline Max & 215 \\
\hline
\end{tabular}

\subsection{Lead $(\mathrm{Pb})$}

The analysis of Lead $(\mathrm{Pb})$ was performed for drain wastewater; drain sludge, soil and groundwater analysis. The values for wastewater and sludge analysis for the drain varies between $0.52 \mathrm{mg} / \mathrm{l}$ to $0.91 \mathrm{mg} / \mathrm{l}$ and $0.57 \mathrm{mg} / \mathrm{L}$ to $0.83 \mathrm{mg} / \mathrm{L}$ with their average mean values $0.751 \pm 0.105$ and $0.675 \pm 0.117 \mathrm{mg} / \mathrm{L}$ respectively. While the values for groundwater were ranging between 0 to $0.08 \mathrm{mg} / \mathrm{L}$ with the mean value $0.04 \pm 0.13 \mathrm{mg} / \mathrm{L}$. Analysis of variance (ANOVA) under the complete randomize design (CRD) showed that the results are non-significant for the wastewater and sludge analysis whereas the groundwater showed significant behavior.

Obtained values after analysis were compared with standard values of USEPA for drinking water, FAO for irrigation water and NEQS for water treatment. Standard values for drinking water, wastewater and irrigation water are given in appendix.

Table 8: Statistical analysis of $\mathrm{Pb}$ Concentration in Wastewater, sludge and soil

\begin{tabular}{|l|l|l|l|l|}
\hline \multicolumn{2}{|l|}{ Statistical analysis } & Wastewater & Sludge & Soil \\
\hline \multirow{2}{*}{ Mean } & $0.751 \quad \pm$ & 0.763 & \pm & $0.693 \pm 0.254$ \\
& 0.105 & 0.117 & \\
\hline SD & 0.105 & 0.117 & 0.254 \\
\hline \multirow{2}{*}{ Range } & Min & 0.52 & 0.698 & 0.670 \\
\cline { 2 - 5 } & Max & 0.91 & 0.796 & 0.720 \\
\hline
\end{tabular}

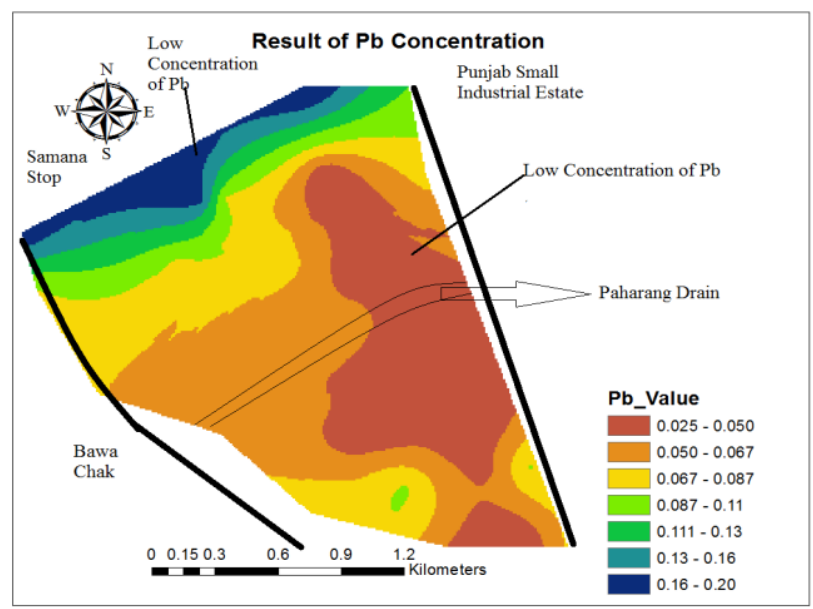

Figure 13: GIS map of $\mathrm{Pb}$

The GIS study shows that $\mathrm{Pb}$ level was very high in drain wastewater and sludge samples. The groundwater samples show lower level of $\mathrm{Pb}$ along the drain. $\mathrm{Pb}$ concentration was high near the Small Industrial Estate. The GIS study shows that the lateral movement of lead $(\mathrm{Pb})$ particles is more toward the left side than the right side due to Groundwater flow pattern.

\subsection{Cadmium (Cd)}

The analysis of cadmium (Cd) was performed for drain wastewater; drain sludge, soil and groundwater analysis. The values for wastewater and sludge analysis for the drain varies between $0.77 \mathrm{mg} / \mathrm{L}$ to $1.61 \mathrm{mg} / \mathrm{L}$ and
$1.42 \mathrm{mg} / \mathrm{kg}$ to $1.90 \mathrm{mg} / \mathrm{kg}$ with their average mean values $1.21 \pm 0.92$ and $1.59 \pm 0.92 \mathrm{mg} / \mathrm{kg}$ respectively. While the values for groundwater were ranging between 0.003 to $0.0057 \mathrm{mg} / \mathrm{L}$ with the mean value $0.004 \pm 0.13$ $\mathrm{mg} / \mathrm{L}$. Analysis of variance (ANOVA) under the complete randomize design (CRD) showed that the results are non-significant the groundwater.

Obtained values after analysis were compared with standard values of USEPA for drinking water, FAO for irrigation water and NEQS for water treatment. Standard values for drinking water, waste water and irrigation water are given in appendix.

According to the NEQS standards the permissible limit for cadmium (Cd) is $0.003 \mathrm{mg} / \mathrm{L}$. The wastewater contend particular amount of cadmium concentration while the ground water samples contain non-poisonous range for irrigation purposes.

Table 9: Statistical analysis of concentration of Cd in Wastewater, sludge and soil

\begin{tabular}{|l|l|l|l|l|}
\hline \multicolumn{2}{|l|}{ Statistical analysis } & Wastewater & Sludge & Soil \\
\hline Mean & $1.21 \pm 0.92$ & $1.59 \pm 0.92$ & $1.485 \pm 0.23$ \\
\hline SD & 0.35 & 0.40 & 0.23 \\
\hline \multirow{2}{*}{ Range } & Min & 0.77 & 1.42 & 1.16 \\
\cline { 2 - 5 } & Max & 1.60 & 1.90 & 1.81 \\
\hline
\end{tabular}

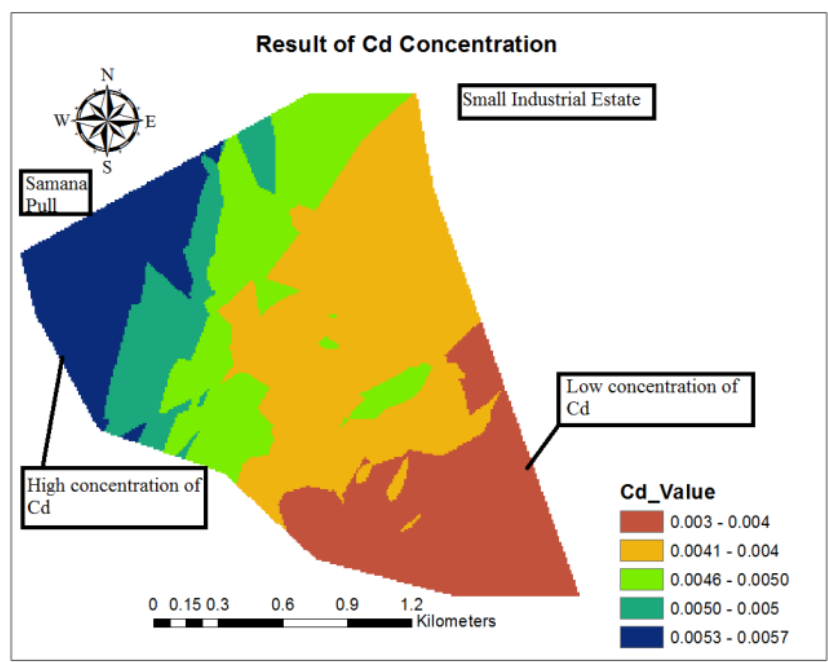

Figure 14: GIS map of Cd

The study explores that Cd level was very high in drain wastewater and sludge samples. The groundwater samples show low level of $\mathrm{Cd}$ along the drain. The GIS study shows that the lateral movement of Cadmium (Cd) particles is more toward the left side than the right side.

\subsection{Chromium (Cr)}

The analysis of chromium (Cr) was performed for drain wastewater, drain sludge, soil and groundwater analysis. The values for wastewater and sludge analysis for the drain varies between $1.00 \mathrm{mg} / \mathrm{L}$ to $2.11 \mathrm{mg} / \mathrm{L}$ and $175 \mathrm{mg} / \mathrm{kg}$ to $191 \mathrm{mg} / \mathrm{kg}$ with their average mean values $1.608 \pm 0.387$ $\mathrm{mg} / \mathrm{L}$ and $182.5 \pm 0.12 \mathrm{mg} / \mathrm{kg}$ respectively. The concentration of $\mathrm{Cr}$ in soil ranging from $120 \mathrm{mg} / \mathrm{kg}$ to $156 \mathrm{mg} / \mathrm{kg}$ with an average mean of $139.75 \pm 0.234$. While the values for groundwater were ranging between 0.023 to $0.043 \mathrm{mg} / \mathrm{L}$ with the mean value $0.031 \pm 0.13 \mathrm{mg} / \mathrm{L}$. Analysis of variance (ANOVA) under the complete randomize design (CRD) showed that the results non-significant for the groundwater analysis.

Obtained values after analysis were compared with standard values of USEPA for drinking water, FAO for irrigation water and NEQS for water treatment. Standard values for drinking water, waste water and irrigation water are given in appendix. According to the NEQS standards the permissible limit for chromium $(\mathrm{Cr})$ is $1.0 \mathrm{mg} / \mathrm{L}$. The wastewater content particular amount of lead concentration while the ground water samples contain non-toxic range for irrigation purposes. 
Table 10: Statistical analysis of concentration of $\mathrm{Cr}$ in Wastewater, sludge and soil

\begin{tabular}{|c|c|c|c|c|}
\hline \multicolumn{2}{|c|}{$\begin{array}{l}\text { Statistical } \\
\text { analysis }\end{array}$} & Wastewater & Sludge & Soil \\
\hline \multicolumn{2}{|l|}{ Mean } & $1.608 \pm 0.387$ & $0.182 \pm 0.12$ & $0.139 \pm 0.234$ \\
\hline \multicolumn{2}{|l|}{ SD } & 0.387 & 0.12 & 0.234 \\
\hline \multirow[t]{2}{*}{ Range } & Min & 1 & 0.175 & 0.120 \\
\hline & Max & 2.11 & 0.191 & 0.156 \\
\hline
\end{tabular}

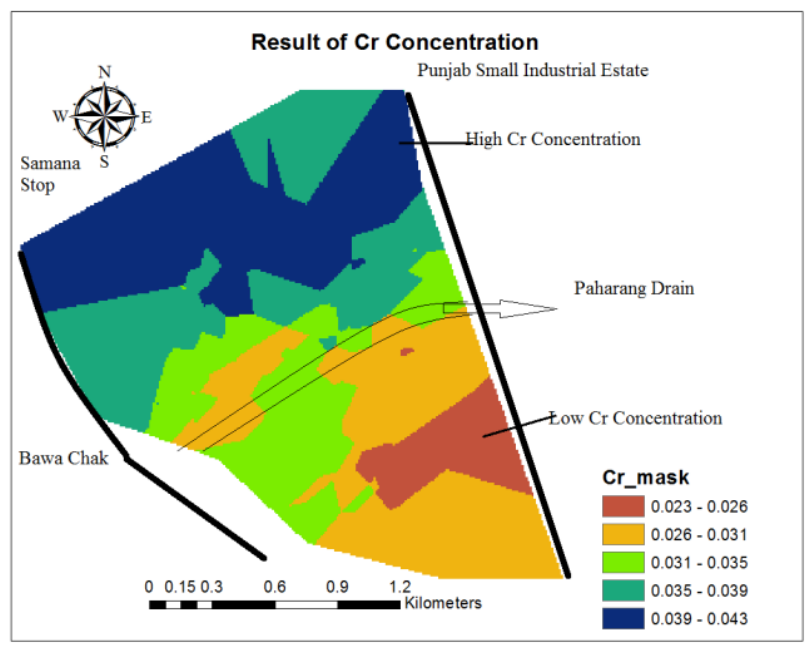

Figure 15: GIS map of $\mathrm{Cr}$

GIS map shows different areas with their chromium (Cr) concentrations which are shown with different legends. The lowest chromium (Cr) was found in the groundwater samples which were taken from the area near the Lassani pulli and Suigas colony while chromium $(\mathrm{Cr})$ concentration was found high nea Smana Pull and Small Inustrial Estate.

\subsection{Cupper (Cu)}

The analysis of Cupper $(\mathrm{Cu})$ was performed for drain wastewater; drain sludge, soil and groundwater analysis. The values for both wastewater and sludge analysis for the drain varies between $0.83 \mathrm{mg} / \mathrm{L}$ to $1.06 \mathrm{mg} / \mathrm{L}$ with their average mean values $0.895 \pm 0.387$ and $105 \mathrm{mg} / \mathrm{kg}$ to $123 \mathrm{mg} / \mathrm{kg}$ with an average mean of $114 \pm 0.01$ respectively. The soil has $\mathrm{Cu}$ concentration ranging from $109 \mathrm{mg} / \mathrm{kg}$ to $135 \mathrm{mg} / \mathrm{kg}$ with an average mean of $120.5 \pm 0.02$. While the values for groundwater were ranging between 0.64 to $1.024 \mathrm{mg} / \mathrm{L}$ with the mean value $0.85 \pm 0.21 \mathrm{mg} / \mathrm{L}$. Analysis of variance (ANOVA) under the complete randomize design (CRD) showed that the results are non-significant for the groundwater.

Obtained values after analysis were compared with standard values of USEPA for drinking water, FAO for irrigation water and NEQS for water treatment. Standard values for drinking water, waste water and irrigation water are given in appendix. According to the NEQS standards the permissible limit for Cupper $(\mathrm{Cu})$ is $2 \mathrm{mg} / \mathrm{L}$. The wastewater contends particular amount of Cupper $(\mathrm{Cu})$ concentration while the ground water samples contain non-poisonous range for irrigation purposes.

Table 11: Statistical analysis of concentration of $\mathrm{Cu}$ in Wastewater, sludge and soil

\begin{tabular}{|c|c|c|c|c|}
\hline \multicolumn{2}{|c|}{$\begin{array}{l}\text { Statistical } \\
\text { analysis }\end{array}$} & Wastewater & Sludge & Soil \\
\hline \multicolumn{2}{|l|}{ Mean } & $0.895 \pm 0.387$ & $0.114 \pm 0.01$ & $0.120 \pm 0.02$ \\
\hline \multicolumn{2}{|l|}{ SD } & 0.387 & 0.01 & 0.02 \\
\hline \multirow[t]{2}{*}{ Range } & Min & 0.83 & 0.105 & 0.109 \\
\hline & Max & 1.06 & 0.123 & 0.135 \\
\hline
\end{tabular}

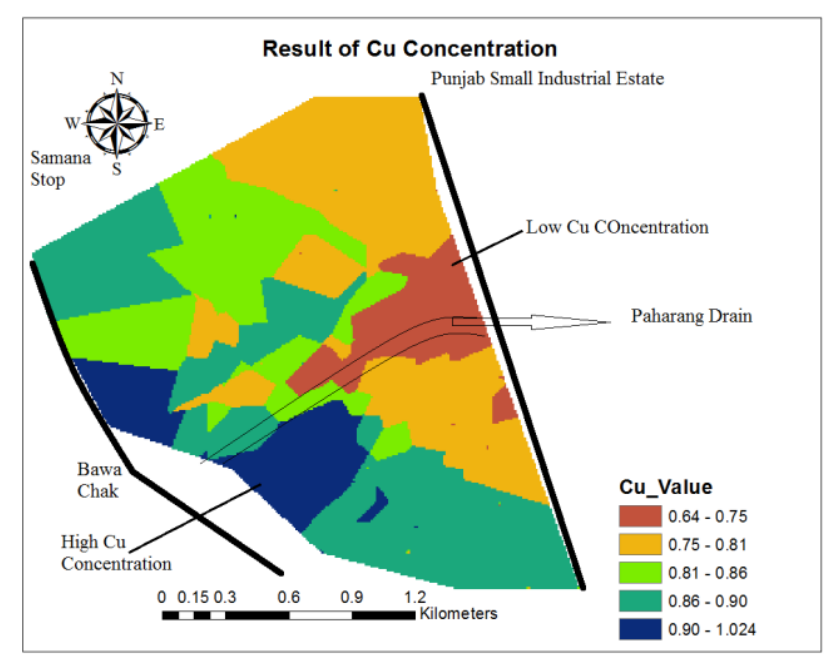

Figure 16: GIS map of $\mathrm{Cu}$

GIS map shows different areas with their copper $(\mathrm{Cu})$ concentrations which are shown with different legends. The lowest $\mathrm{Cu}$ was found in the groundwater samples which were taken from the area near the Panj Pulli while $\mathrm{Cu}$ concentration was found high near Bawa Chak.

\section{CONCLUSION}

From the GIS mapping it has been found that higher concentrations of almost all the parameters under investigation have been observed on the northern side of the research area. Northern side being the center of the city and densely populated seems to be more exposed to the threat of spreading contamination of all the parameters including basic as well as heavy metals in the groundwaters. Other parameters related to wastewater characteristics, particularly BOD and COD values have shown higher values in the drain, indicating a potential threat to percolation of the pollutants into soil and groundwater. It can be confirmed by the moderately higher values of these parameters in soil and groundwater as well. It is highly recommended that the drain should be lined and the industrial units should be compelled to install individual treatment units within industries. Furthermore pumping of groundwater should be prohibited along the drain.

\section{REFERENCES}

[1] Shah, T. 2000. Groundwater markets and agriculture development: a south asian overview. In: Proceedings of regional groundwater management seminar, Pakistan Water Partnership, 9-11.

[2] APHA. 2003. Standard methods for the examination of water and wastewater, 21st ed. Washington, DC, American Public Health Association, American Water Works Association and Water Environment Federation.

[3] AOAC. 2007. Official Method of Analysis. Association of Official Analytical Chemists 18th Ed. Arlington, USA.

[4] Aziz, M.A. 2001. Interactive effect of Nickel, Zinc and lead on their movement in soil and translocation into plant. M. Sc. Thesis, Dept. Soil Sci., Uni. Agri., Faisalabad, Pakistan.

[5] Greenberg, A.E., Clesceri, L.S., Eaton, A.D. 1992. Standard Methods for the Examination of Water and Wastewater, American Public Health Association, Washington, D.C.

[6] Nasir, A., Arslan, C. 2012. Physical analysis of groundwater at thickly populated area of Faisalabad by using GIS. Pakistan journal of Agriculture and Science, 49, 541-547. 